\title{
Crisis Leadership of the Bush Presidency: Advisory Capacity and Presidential Performance in the Acute Stages of the 9/11 and Katrina Crises
}

\author{
PAUL 'T HART \\ Australian National University and Utrecht University \\ KAREN TINDALL \\ Australian National University \\ CHRISTER BROWN \\ Swedish National Defence College
}

\begin{abstract}
This paper examines the operation of the presidential advisory system during the 9/11 and Hurricane Katrina crises in order to explain the marked differences in presidential crisis leadership performance during the acute phase of both crises. It first presents a conceptual framework for the systematic study of "crisis advisory configurations" around presidents, based on an integrated review of the advisory systems and crisis management literatures. Second, the framework is applied to George W. Bush's performance in three crucial crisis leadership task domains—sense making, decision making, and meaning making. The article concludes by identifying key challenges of building crisis management capacity around heads of government such as the U.S. president.
\end{abstract}

"There is no longer such a thing as strategy; only crisis management," U.S. Secretary of Defense Robert McNamara sighed after the experience of the Cuban missile crisis. That surely was an exaggeration, but it does drive home the idea that the ability

Paul 't Hart is a professor of political science in the Research School of Social Sciences, Australian National University, and professor of public administration in the Utrecht School of Governance, Utrecht University. His major research interests include public leadership, political group dynamics, crisis management, policy evaluation. and public accountability.

Karen Tindall is a doctoral candidate in the Research School of Social Sciences, Australian National University. Her major research interests include leadership, crisis management, and foreign policy.

Christer Brown is an analyst at the National Center for Crisis Management Research and Training, Swedish National Defence College, and a doctoral candidate at Nijmegen Institute of Management at Radboud University in the Netherlands.

AUTHORS' NOTE: We would like to thank Arjen Boin, Allan McConnell, Charles Parker, Thomas Preston, Bengt Sundelius, and PSQ's anonymous reviewers for their comments on an earlier draft of this article. 
to respond quickly, sensibly, and responsibly to a wide range of major acute emergencies is now a "must have" for government leaders. Responding to emergencies involves the need to make far-reaching decisions quickly in a context of threat and uncertainty. It also involves coping with the collective stress that emergencies generate (Rosenthal, Charles, and 't Hart 1989). Yet crises are not necessarily just "bad news" for incumbent governments: behind the stress and hardship that major emergencies cause looms an often intricate mix of strategic threats, as well as opportunities, that well-prepared and agile leaders are able to discern and exploit. To be able to tackle crises immediately, effectively, and strategically, government leaders need to perform at least three tasks (Boin, t' Hart, and Sundelius 2005):

1. Sense making: Getting a clear and accurate picture of the events, their impact, and significance

2. Decision making/coordinating: Mobilizing, facilitating and, if need be, adjusting the government's preexisting emergency response and recovery system

3. Meaning making: Taming collective stress by authoritatively explaining the crisis, its implications, and the government's responses to the community.

The three tasks are clearly interrelated. Without adequate high-speed sense making, the thrust of the response operation may be tardy, misguided, or disorganized. Furthermore, when the response operation is going badly, leaders lose the credibility they need to be effective at meaning making.

During George W. Bush's two terms as president, the United States was hit suddenly by two national catastrophes: the 9/11 terrorist attacks and the levee breaches in New Orleans following Hurricane Katrina. They serve here as illustrative, yet "most different" cases, as the timing, perceived adequacy, and popular support for the Bush administration's crisis response varied greatly across these two episodes. In the immediate aftermath of the two catastrophes, the White House's 9/11 response was widely praised, whereas its Katrina response was severely criticized. Bush's personal approval ratings shot up in the aftermath of the 9/11 crisis, whereas after Katrina, they declined markedly, particularly among voter groups such as African Americans and Hispanics. Bush's first address to Congress after 9/11, coming at the end of moving, dignified, and effective local emergency response operations, secured him strong bipartisan support. There was little criticism from the media_left, right or center (see, e.g., Woodward 2008, 429). In contrast, during and after Katrina, Bush bore the brunt of an increasingly harsh public condemnation of the disaster response in New Orleans, characterized by a bipartisan congressional committee labeling the entire Katrina tragedy as "a failure of initiative" (referring to the pre-crisis preparedness and mitigation policies of federal, state, and local governments), but also singling out the (lack of) leadership and responsibility in the emergency response decisions and actions (Select Bipartisan Committee 2005; Sylves 2006).

The detailed narratives of the 9/11 Commission report (2004, 35-42, 325-38), subsequent memoirs, and journalistic accounts (see, e.g., Woodward 2002, 1-109) demonstrate that after President Bush's initial bewilderment upon learning the news (caught on camera in the Florida classroom), he grasped the enormity of what was happening (sense making), was proactive and involved with the government's response process 
(decision making/coordination), and was extraordinarily successful in rallying domestic and international support for his administration's "framing" of the crisis and the government's preferred response to it (meaning making). Hargrove (1998) claims that presidential leadership is largely about "teaching reality," and in the weeks following 9/11, the president's espoused version of reality was widely accepted and disseminated throughout the United States and, indeed, the world (Landy 2004, 50-53). President Bush's performance projected "dignified authenticity" (Gregg 2004, 93-103) and launched him as a potentially "heroic" (Roper 2004) and even, albeit temporarily, "charismatic" (Bligh, Kohles, and Meindl 2004) leader. In contrast, during the Katrina crisis, Bush struggled, and was publicly criticized for struggling, quite badly at all three tasks (Liu 2006; Preston 2008). While it is admittedly difficult to objectively gauge "performance" and "success," it is clear that the general public and the main monitors of government performance were essentially satisfied during the acute phase of the 9/11 crisis, but loathed Bush's leadership during the acute phase of Katrina.

This article asks, why? Why did a president who displayed such effective crisis leadership in his first major crisis fail to replicate it four years later? There are obvious answers to this question. A pivotal one is that 9/11 and Katrina were simply different types of crises. Proponents of this answer will point to differences in the kinds of pre-crisis warnings, crisis triggers, crisis impacts, response and recovery challenges, and intergovernmental balance of responsibilities. Some will say that Ray Nagin was no Rudy Giuliani, and that the crisis management capacity and political clout of Louisiana was much less than that of New York. All that is true. But it begs the fact that both were quickly felt to be not ordinary emergencies but national catastrophes, and that, given that definition of the situation, the entire country was looking to the White House for leadership in both instances-not to micromanage the on-the-ground responses, but to effectively assist local and state authorities and to demonstrate that the government cared, was in control, and was providing the people with a plausible pathway out of the misery of the moment. The country clearly felt it had received such leadership immediately following September 11, 2001, but equally clearly rejected Bush et al.'s response to the emergency along the Gulf Coast in August and September 2005.

We argue that the answer to Bush's differential effectiveness as crisis leader must not be sought just in his own personal performance, but perhaps even more so in the performance of the configuration of advice he relied on. We argue that what we call a "robust advisory configuration," combined with early, intense, and proactive presidential involvement in the crisis management process, made Bush shine in September 2001; the lack of both helped turn the response to Katrina into the "bureaucratic nightmare" (Bier 2006) it became.

Taking the dependent variable to be the perceived quality and adequacy of President Bush's crisis leadership performance in the eyes of relevant stakeholders (including the public and policy actors), we compare and contrast the makeup and modus operandi of the advisory configurations surrounding Bush during both crises. Although the events were of different natures (terrorism versus natural disaster), we consider the cases comparable to the extent that both presented the same president with similar sets of daunting challenges common to most major crisis events. Our argument unfolds as follows: 
First, we construct a conceptual framework for the analysis based on our reading of the literature on advice to government leaders in conjunction with the crisis management literature. Then we apply the framework to examine Bush et al.'s sense making, decision making/coordination, and meaning making in both crises. We conclude by identifying key challenges of building crisis management capacity around heads of government such as the U.S. president.

\section{Advisory Configurations and Crisis Leadership Performance}

Leaders have always needed assistance, and consequently there is a very old and now sizable literature on advice giving and advisory systems for heads of government, going back to Machiavelli (Goldhamer 1978). Traditionally, a lot of attention was focused on the delicate art of advice giving: how to "speak truth to power," when doing so may be unwelcome and therefore risky for the advisor (cf. Meltsner 1988). More recently, advice has been seen increasingly in terms of the institutional capacity of governments: What sources and channels of information and expertise are at their disposal?

In parliamentary systems, much of the relevant research falls under the rubric of (prime) ministerial advisors and offices, with a key issue being the balance between personal staff, the government bureaucracy, and external streams of policy advice to ministers (Bakvis 1995; Campbell and Wyszomirski 1991; Tiernan 2007). Or it ties in with the broader issue of the balance of power in parliamentary systems - for example, raising the much-debated specter of "presidentialization" of the prime ministership, among others, by the expansion of advisory capacity in prime ministers' administrations (Poguntke and Webb 2005).

In presidential systems, but also particularly in the United States, the literature focuses on two areas: the design and management of advisory systems so as to serve the needs and style of their chief clients, as well as to enhance the quality of presidential decision making (George 1980; George and Stern 2002; Hess and Pfiffner 2002; Hult and Walcott 2004; Johnson 1974; Mitchell 2005; Patterson 2000; Walcott and Hult 1995, 2005); and leaders' actual performance in cases where presidential decision making really matters, particularly foreign and security policy (Burke and Greenstein 1989; Haney 1997; Hoyt and Garrison 1997; Janis 1982; Kowert 2002; Pfiffner 2005; Preston 2001; Yetiv 2003), down to the level of highlighting the nature and predicaments of particular advisory roles in the White House makeup, such as chief of staff (Sullivan 2004; Walcott, Warshaw, and Wayne 2001) or national security advisor (Burke 2005). Both strands of the literature apply to the Bush administration (Burke 2004; Haney 2005; Kettl 2003; Kumar 2003; Rudalevige 2005; Vaughn and Villalobos 2006).

\section{Toward a Conceptual Framework}

Two lacunae exist in this literature that are relevant to our research question. First, when gauging the capacity and effectiveness of advisory arrangements surrounding heads of government, the literature rarely acknowledges the continual flux of advisors and 


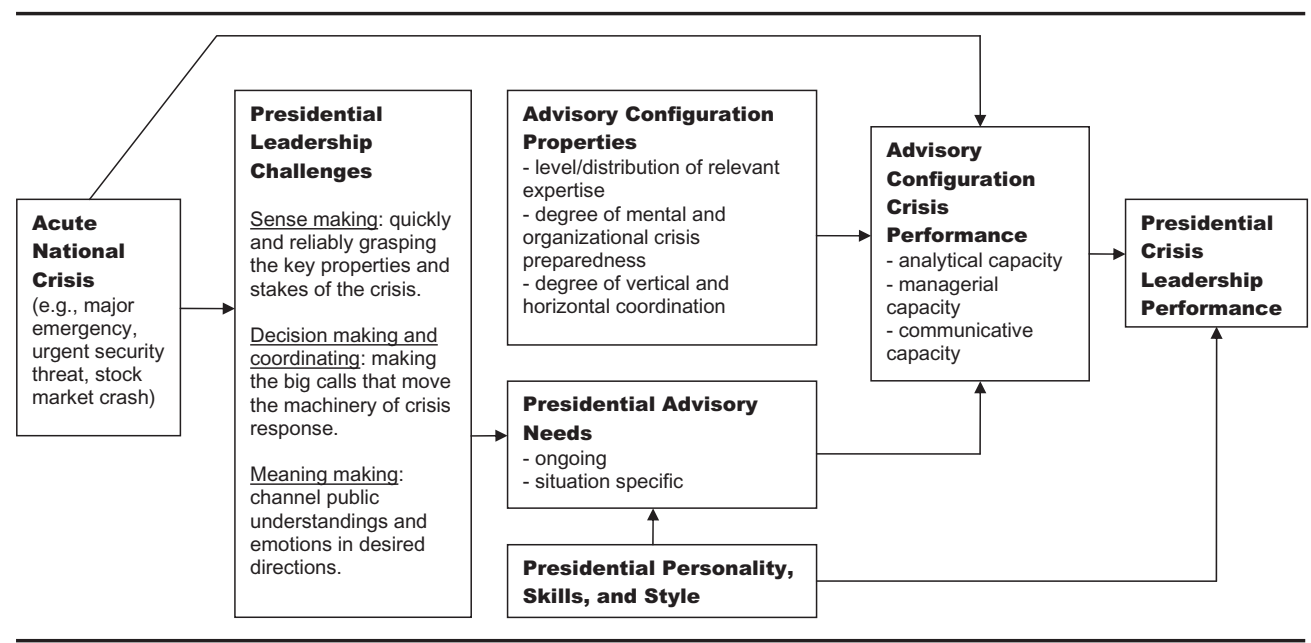

FIGURE 1. Advisory Configurations and Presidential Crisis Leadership Performance: A Framework.

advisory systems that emerges with each challenge and task (but see Hult and Walcott 2004), though most analysts that do acknowledge the existence of variation, looking at the personal characteristics and styles of presidents as the key source of that variation (e.g., Kowert 2002; Preston 2001). The U.S. advisory systems literature, in particular, gets a considerable part of its empirical underpinnings from case studies of presidential crisis management, yet it has not really conceptualized the specific challenges of advising leaders in these circumstances. Hence, it is fair to ask what kinds of demands do the key strategic challenges of crisis leadership — sense making, decision making/coordinating, and meaning making-place on leaders' advisory systems? In our view, there are two basic variable clusters to be taken into consideration, with the focus of this article being on the first of the two. We discuss both here and present a conceptual framework that is summarized in Figure 1.

First, the task orientation: Does the leader get what he or she needs to effectively govern under acute crisis conditions of threat or disturbance, urgency, and uncertainty? As noted, acute crisis leadership entails three critical tasks: sense making, decision making/ coordination, and meaning making. Effective advisory arrangements enable leaders to perform these tasks successfully. They need to have the capacity to do the following:

1. Engage in high-speed, dynamic, yet reliable situational diagnosis, in order to assist the leader's sense making. We call this the analytical crisis capacity of advisory arrangements.

2. Identify and analyze strategic policy and machinery-of-government challenges involved in responsibly running large-scale, complex, and sensitive emergency response operations, in order to assist the leader's decision making and implementation coordination role. We call this the managerial crisis capacity of advisory arrangements.

3. Produce texts and stage-manage public communications in the context of collective stress generated by the occurrence of crisis in the community affected and the nation as a whole, in order to assist the leader's meaning making. We call this the communicative crisis capacity of advisory arrangements. 
The second variable cluster to consider is the personal support orientation: Does the leader have people to turn to who can help him or her cope with the extraordinary pressures and consequent high levels of stress that crises tend to generate? Is the leader likely to falter when under pressure? And if so, what types of assistance does he or she seek? Milburn (1972) notes that under crisis-induced stress, leaders turn to "trusted, liked sources." Furthermore, these "trusted, liked sources" may not necessarily be part of the official advisory system, but could also include spouses, longtime friends, and peers (Rosenthal and 't Hart 1991). Likewise, Burke and Greenstein recognize that Richard Tanner Johnson's 1974 classifications of presidential advisory systems (formalistic, competitive, and collegial) are "too few and too simple," and there is a need to take into account a "mixture of formal and informal procedures" (1989, 274-75). From a normative perspective, this may be troublesome, as it involves highly informal, nontransparent, unaccountable forms of influence. But it is a fact of life. Hence the need to add a final criterion to the list: the psychological support capacity of advisory arrangements-for example, their ability to safeguard the leader's ability to function in the face of extreme physical, political, or emotional pressures.

The psychological dimension of leaders' crisis responses is perhaps the most challenging empirical puzzle for students of contemporary crisis management episodes. It often takes years, if not decades, before the human realities behind the carefully maintained façade of an in-control leader emerge, as with the onset of World War I (Holsti 1972) or the Cuban missile crisis (Blight 1990). Hence, while we will not be able to perform this analysis for the Bush cases, we acknowledge its potential influence. Suffice to say that President Bush and his entourage certainly were not immune to the anger, grief, and bewilderment that 9/11 caused. Bush unexpectedly shed tears at least twice during the first week of the 9/11 crisis, leaving some of his advisors, notably Colin Powell, wondering whether he was able to cope (Woodward 2002, 65). Clearly, there is a story to tell about who or what helped Bush maintain the public composure he demonstrated throughout the crisis. However, lacking more in-depth source materials, it cannot be told just yet. Therefore, the remainder of this paper focuses on the functional dimension of crisis advice.

The second missing element in the literature is that it often mixes up advisory systems, advisors, and advisory processes. Numerous scholars are interested in the structure of advisory systems, as demarcated by formal and spatial boundaries, such as "Number 10" (Kavanagh and Seldon 1999), or the "White House staff" (Patterson 2000). This helps them understand the institutional dynamics of the power game surrounding leaders, but not to track its actual (crisis) performance in particular historical cases. Others are more focused on the advisory processes, mostly denoted as the operation of "inner circles" ("kitchen cabinet," "war cabinet") of "principals" around a president or prime minister (Preston 2001). These studies analyze advice given in terms of smallgroup dynamics (Garrison 2007; Garrison, Hoyt, and Wituski 1997; 't Hart, Stern, and Sundelius 1997; Redd 2005).

Although a small-group focus is essential for understanding crisis leadership processes, analysts in this vein tend to ignore the importance of the lower tiers of information, expertise, and advice that service the top-level advisors who participate in the leadership 
group. U.S. cabinet secretaries or senior White House officials are also leaders of sometimes vast entities whose output equals their raw material with which to advise the president. They cannot do so effectively if their own staff does not provide the best possible lines at the best possible time. Hence the small-group perspective is necessary but not sufficient when analyzing advisory arrangements and their impact on (crisis) leadership.

For our present purposes, it is useful to look at what we call crisis advisory configurations, defined as the cluster of formal and informal advisors, as well as the relevant components of their "back offices" that on a de facto basis provide counsel to a leader during the immediate response phase of an emergency episode. ${ }^{1}$ For various reasons, crisis configurations may differ significantly from the full-scale, formal (or expected) advisory system: key advisors may be absent or unable to be reached when the crisis hits and, as such, require considerable time to get back into the loop; initial ways of framing the events may cause some high-level advisors to be left out of the inner circle of crisis deliberation; or ongoing bureaupolitical strife in the advisory system may produce deliberate efforts to manipulate the composition of the inner circle. Moreover, the configuration approach explicitly looks at the nexus between high-level advisors and their own organizational back offices: what information and services flow upward from secondand third-tier officials to the senior advisors or directly to the leader?

We are under no illusion that good advice guarantees effective crisis leadership, and we fully accept that other factors are likely to explain part of the variation in crisis leadership performance that may be found across cases involving the same leader or administration, such as 9/11 and Katrina. Obviously, the role of the leader is likely to be pivotal, particularly the leader's own (initial and evolving) definition of the situation and, partly as a consequence of this, the degree of leader involvement in the crisis management process. However, we suspect that the crisis capacity of these advisory configurations significantly affects crisis leadership performance. In turn, this advisory crisis capacity is posited to be shaped by the confluence of (1) the level and distribution of expertise in the composition of the configuration; (2) the degree of mental and organizational preparedness for the type of crisis at hand within the configuration; and (3) the degree of vertical and horizontal coordination between the various nodes in the configuration in informing and assisting the leader.

\section{Sources and Caveats}

For each case, we rely on available published inquiries, investigative journalism monographs, contemporaneous media coverage, and scholarly interpretations to develop our account of the key components in our model: crisis leadership challenges, leader perceptions and involvement, advisory configuration makeup, revealed crisis capacities,

1. Much of the literature employs a rather limited notion of what constitutes an advisor. It focuses on officeholders, ignoring the opaque but potentially vital role of unofficial advisors such as spouses (Nancy Reagan is a famous case), family members, lifelong friends, "cronies" (Eisenhower's "gang" of golf buddies, the infamous "Bebe" Rebozo for Nixon), and personal physicians, coaches, or therapists. However, this largely fits into the psychological dimension of leaders' crisis responses, which we have already deemed to be beyond the feasible scope of this study. 
and crisis leadership performance. Some caveats apply. First, our analysis only applies to the acute stages of both crises, which obviously endured for much longer. Strategic response decisions that gain or lose support for a leader and portray an (in)effective crisis manager during the acute phase are not necessarily indicative of the leader's long-term crisis leadership. ${ }^{2}$ However, the acute stage merits close analysis because it provides the initial foundations for the leader. While it is by no means the only starting point for in-depth studies of crisis leadership, it is a significant stage on which to focus. In the 9/11 case, our analysis covers the events from the day of the attacks up to Bush's speech before Congress on September 20, 2001, which rounded off the meaning-making process and conveyed the key strategic crisis leadership decisions made regarding the immediate crisis at hand (see, e.g., 9/11 Commission 2004, 35-42, 325-38). The Katrina analysis covers events from Hurricane Katrina's landfall on August 29 up to September 4, 2005 , the day after the president approved the deployment of active-duty federal troops. By this time, most victims were on evacuation buses or already out of harm's way; shelters, food, and water were already in place or en route. Second, due to length limitations, we shall not recount the basic course of events in both crises, which we assume to be common knowledge. Third, the focus of this article is on the U.S. presidential system (and the Bush administration in particular). Nonetheless, the general concepts and conclusions regarding advisory configurations have relevance across other executive systems and are interesting areas for further research. Finally, given the source limitations and the likelihood that even more in-depth data about the workings of the Bush White House during both crises will become available in the future, we reiterate that we are focusing on task orientation rather than personal support orientation and accept that our account cannot be but a provisional one.

\section{Advisory Configurations and Crisis Leadership Performance: A Case Comparison}

In the first stage of the analysis, we look at the crisis advisory configuration of each crisis. Then we look at how these configurations facilitated and constrained each of the three challenges of the president's crisis leadership: sense making (requiring analytical advisory capacity), decision making (managerial advisory capacity), and meaning making (communicative advisory capacity).

\section{Advisory Configurations}

The 9/11 crisis. The attacks occurred on a weekday morning, a full week after the end of the U.S. holiday period. As a result, the machinery of government was fully staffed

2. What is at one point deemed to be effective crisis leadership during the acute phase of a crisis can later be viewed as inappropriate. Clearly, evaluations of Bush's leadership in the aftermath of 9/11 shifted in the post-acute phase, once the administration chose to invade Afghanistan and, particularly, Iraq as part of the "war on terror" declared in response to $9 / 11$. However, the dynamics of the transition to post-acute-stage challenges of crisis leadership, while an interesting research question, are outside the bounds of this particular study. 
and all of the key principals in the White House and the National Security Council except Secretary of State Powell (in Peru at the time) were at work, either in Washington or accompanying the president during a visit to Florida when the attacks occurred. The advisory configuration that emerged on 9/11 therefore closely resembled the formal structure of the National Security Council advisory system, both at its senior-most levels and its lower tiers.

Bush had been president for nearly eight months when the attacks occurred, and his national security advisory arrangement had had time to crystalize. At the level of the principals, it was populated by a highly experienced team, many of whom had served under Bush's father and other presidents, and who for the most part knew each other well, respected one another, and thought along similar ideological and strategic lines (Mann 2004). Furthermore, for political and communications advice, Bush relied very heavily on two key people from his gubernatorial days who were placed in pivotal White House positions, namely political advisor Karl Rove and Counselor to the President Karen Hughes. The top-level team, as well as the team of deputies that met separately, worked well during the acute phase of the 9/11 crisis: despite important differences of opinion, such as the desirability of attacking Iraq in addition to Afghanistan, deliberations were characterized by vigorous debate and a marked absence of in-fighting. (However, in-fighting on these issues would later become quite intense.) Bush was much more involved, focused, and proactive in the deliberation process than his regular leadership would suggest (cf. Preston and Hermann 2004). Condoleezza Rice focused on taming the inevitable first-response chaos by structuring the National Security Council deliberation process to bring all relevant perspectives to the table. Burke (2005) goes so far as to depict her as a model "honest broker" role, complementing the similarly procedurally focused role played by Chief of Staff Andrew Card throughout the early years of the Bush presidency.

The Katrina crisis. In contrast, Hurricane Katrina made landfall when the country and the administration were still in summer mode, with the president at his ranch in Crawford, Texas, and several key officials, including Vice President Dick Cheney and Chief of Staff Card, on vacation. Gearing up for crisis response is inevitably much more difficult under these circumstances, modern communication technologies and organizational routines for replacing top leaders notwithstanding. Perhaps more importantly, the advisory configuration that emerged during the Katrina crisis differed in significant ways from that during 9/11. This was, after all, a purely domestic issue. Different federal organizations and players were placed at the forefront of emergency response operations than if additional al-Qaeda attacks had materialized. Moreover, much more so than in September 2001, the administration was to a large extent reliant on information coming from local and state authorities, which forms the first lines of disaster response in the United States. There was also considerable uncertainty about the extent of federal powers and responsibilities in a truly catastrophic emergency. Taking into account the institutional context at the time, the newly created Department of Homeland Security (DHS) had swallowed up the Federal Emergency Management Agency (FEMA), leaving its top officials feeling debased and cut out of the loop. Moreover, there were disjunctures between the understandings of top officials (in the White House, as well as 
political appointees in FEMA and the DHS) and FEMA professionals, who considered it common knowledge that a Category 3 hurricane could cause devastation in New Orleans (Lewis 2008, 168). Also, a new National Response Plan, introduced prior to landfall determination, had created a category of "catastrophic incidents." Once an event was declared as such, the federal government would take charge of the entire response effort. However, clear criteria for making that clearly were not stipulated, and the plan had not yet been exercised in any meaningful manner (McQuaid and Schleifstein 2006, 225-6). Moreover, FEMA's role had always been, and still is, not so much to "take over" but to coordinate federal assistance to state and local authorities.

Hurricane Katrina laid bare the institutional complexities, teething problems, and hidden vulnerabilities of the United States' crisis response reforms. The resulting fragmentation of authority across agencies and layers of government spilled over into the advisory configuration that emerged during Katrina. Key players in the federal emergency response system were either too far removed from the inner circle of top advisors to the president (e.g., FEMA director Michael Brown, who actually sought to deviate from the National Response Plan when he repeatedly attempted to coordinate operations through the White House rather than the DHS secretary) or maintained too distant relations with the White House (DHS secretary Michael Chertoff) to be in a position to provide effective advice to the president.

Other key players who could have been crucial in keeping the president abreast of the unfolding catastrophe, notably Louisiana governor Kathleen Babineaux Blanco and New Orleans mayor C. Ray Nagin, were themselves overwhelmed by the sheer magnitude of the disaster. Nagin would eventually succumb to stress, effectively dropping out of view for long periods of time, while Blanco and her officials became increasingly suspicious of alleged White House blame-shifting machinations, distrusting reports coming from Washington. Bush's most trusted aides-Card, Rove, Counselor to the President Dan Bartlett, and Frances Townsend, the head of the Homeland Security Council at the White House-were nowhere near as influential in controlling the flows of information, advice, deliberation, and external communications as they had been during the 9/11 crisis.

\section{Shaping Presidential Sense Making: Analytical Capacity}

The 9/11 crisis. Chief of Staff Card conveyed the magnitude of the situation from the get-go when he told Bush, "America is under attack." Bush et al. were faced with three key sense-making challenges: (1) ascertaining the scope and depth of the current wave of attacks; (2) gauging the possibility of follow-up attacks in the near future; and (3) articulating the geostrategic implications of the attacks. Because the magnitude of the situation was evident from the moment the second plane hit the World Trade Center, the entire Bush administration was working on that one issue, and all possible information and resources were available to Bush and his advisors. This can make a huge difference when compared with lesser or more creeping crises, when the case for reallocation of attention and resources to the crisis is less compelling.

Moreover, although the sheer scale and ferocity of the attacks came as a surprise, key players within the advisory configuration, particularly Central Intelligence Agency 
director George Tenet, had long been concerned about the risk of just such an attack occurring on the U.S. mainland. Although the system had failed badly at "connecting the dots," and thereby possibly preventing the attacks in the first place, the preexisting recognition of the al-Qaeda threat with in the U.S. intelligence and security community did mean that a great deal of relevant information and expertise was readily on hand when the crisis occurred. Key advisors had been "primed" to deal with an issue such as this; many of them had firsthand experience operating in major national security or foreign policy crises. Days after the attack, vigorous discussions took place during a weekend retreat for the National Security Council principals about the strategic implications of the attacks. Bush was highly involved in the deliberations; Rice managed the process proactively to make sure all perspectives were considered.

Combined, these factors ensured that the analytical capacity of the 9/11 advisory configuration was high. This was an important asset, particularly for a president with little prior security and foreign policy expertise, and clearly contributed positively to the speed and accuracy of presidential sense making about the cause of the attacks, the identities of the culprits, the organization that they represented, and the country where many of their handlers and additional terrorists were harbored. This is not to suggest that sense making was devoid of problems. For instance, it later became clear that, initially, Bush was keen to explore possible ties to Iraqi. When told by Richard Clarke that the attacks had been carried out by al-Qaeda, not the Iraqi government, Bush told him to have his team take another look at the Iraq angle, a distraction of attention and staffing at the time (and arguably the seeds of future failures regarding the Iraq invasion decision). Furthermore, Bush was not well served by all of his advisors. Donald Rumsfeld, as he testified before the 9/11 Commission, was one of the advocates for targeting Iraq in response to the 9/11 attacks. Paul Wolfowitz also made this case. Fortunately, other top-tier advisors, such as Powell, who was at the much-discussed Camp David war council meeting on September 15-16, made a strong enough case to focus the U.S. government's attention first on al-Qaeda and the Taliban. Ultimately, the system worked in the September 2001 case: the analytical capacity of Bush's advisory configuration was able to provide him with enough good information and robust debate that his sense making was rapid and effective, and further facilitated strategic response decisions and meaning making in the acute phase.

The Katrina crisis. As in the 9/11 case, the president was faced with three evolving sense-making challenges during the early days of Katrina: (1) assessing the damage to New Orleans's levees — whether the hurricane had caused a mere over topping or a full-scale break (in which case a major catastrophe requiring massive federal assistance would definitely result); (2) assessing the extent of human suffering and material damage caused by any such levee breaches; (3) ascertaining the magnitude of the problems with the ongoing response operation and the urgency of need for federal assistance. When looking at the sense-making activities in Bush's advisory configuration, the comparison between 9/11 and Katrina reveals a paradox: although hurricanes, unlike terrorist attacks, are common in the United States (and, indeed, Chief of Staff Card had been directly involved in the George H. W. Bush's management of Hurricane Andrew in 
Florida), sense making during Katrina proved to be much more problematic than during 9/11, not just for the president, but for the entire government. Seemingly straightforward questions answerable by simple physical observation, such as the occurrence, location, and magnitude of the levee breaks, proved much more difficult to answer. News regarding levee breaks had a hard time reaching the White House and the president in particular (Cooper and Block 2006, 131-76; McQuaid and Schleifstein 2006, 211-26). As a result, Bush was practically deprived of timely, accurate, and comprehensive information about events "on the ground." In these circumstances, watching televisionwhich he did infrequently — would have given him more of a sense of what was going on than the belated, unduly skeptical, or ambivalent reports that were coming to the White House from various back offices and state governments.

Prior to landfall, Bush and his staff had received clear warnings of the potential implications of a Category 4 or 5 hurricane hitting New Orleans. The severity and consequences of Katrina had been predicted and communicated to the White House prior to landfall by Director Max Mayfield of the National Hurricane Center. Bush did not appear to question or fully grasp the implications of these dire predictions. Nor, for that matter, did any of the president's inner circle. After landfall, those who should have been able to recognize that this was a national catastrophe as described in the National Response Plan (FEMA director Brown, DHS secretary Chertoff) did not have the access, skills, or fungible back office support to provide effective advice to the president. (Brown for one tried to reach the president but failed.) It has also been suggested that Chertoff was not aware of what authority he held under the National Response Plan (Lewis 2008, 166). In fact, the crucial back office information nodes, such as the Homeland Security Operation Center (HSOC) — and, to a lesser extent, the White House Situation Roomconsistently failed to effectively and speedily absorb, integrate, analyze, and transmit the information provided to them from the field. The HSOC in particular persisted in downplaying the situation despite overwhelming evidence to the contrary; the HSOC director was unfamiliar with the specific threat facing New Orleans and saw reports of flooding as "normal hurricane" and thus was hesitant reporting to issue initially what he considered to be overly alarmist reports.

Likewise, those advisors who were actually with Bush and tended to have his ear (including Deputy Chief of Staff Joe Hagin, Karl Rove, and Dan Bartlett) gave communications and tactical advice but themselves lacked alternative channels of information and expertise to fill the "communication void" that debilitated the White House's sense making (U.S. Senate 2006, 287-97). Finally, in direct communications with Bush, the Louisiana governor-not exactly an advisor to Bush, but nevertheless a potentially crucial source of information and sense of urgency on the matter-also failed initially to effectively communicate the true scale of the disaster and the need for more than routine federal aid. She lacked an understanding of the formal procedures in place for requesting federal assistance, and thus her requests were not properly dealt with.

In short, there was no "common operating picture" (White House 2006, 36), resulting in a persistent "lack of situational awareness" (U.S. Senate 2006, 303-14) which became a major source of frustration and even anger for Bush as the week progressed. 


\section{Facilitating Presidential Decision Making and Coordination: Managerial Capacity}

The 9/11 crisis. The attacks hit New York City, a well-resourced and wellprepared jurisdiction when it comes to emergency management, as well as the Pentagon, a federal government bulwark, with the fourth plane crashing in a field in rural Pennsylvania. As such, there was no ambiguity about the distribution of responsibility and authority: New York mayor Giuliani was in charge of local response and recovery operations, whereas the Pentagon ran its own operations, with the crash of the fourth plane essentially eliciting a "routine" crash site response by local as well as federal aviation and law enforcement authorities. Other than responding to requests for federal financial support for the reconstruction work in New York City, Bush and the National Security Council were therefore largely free to concentrate on other issues - in particular, the immediate threat of more attacks (potentially targeting the president or the White House), the main strategic and symbolic issues of when and how to respond to the attacks, and the task of portraying the president as both the commander in chief and what has been labeled the role of "comforter in chief."

In the first hours of the crisis, with Bush literally in the air, Vice President Cheney filled the vacuum and made a number of quick decisions to address the immediate threat of further attacks, particularly the decision to authorize the use of force against passenger planes that were confirmed security threats. Halting all regular air traffic in U.S. air space was another of these short-term security decisions. Likewise, Rumsfeld began pressing the Joint Chiefs of Staff for contingency plans so as to be able to provide Bush with concrete military options. Powell was handicapped by his physical absence from Washington and the limited communication facilities available on his plane, but thereafter quickly went about gauging and mustering international support so as to provide Bush with insight into the ramifications of alternative policy options that were on the table.

After Bush's return to Washington, a series of improvised (but later in the week, more methodical) deliberations were conducted to discuss military and diplomatic response options. There was a certain degree of time pressure involved because, after Bush's improvised remarks immediately after learning about the attacks ("this will not stand") and his subsequent use of explicit war rhetoric when referring to the events, Congress, the media, the American public, and the international community were all keenly waiting to see what the administration would do. However, there was no "objective" time pressure in the sense that live victims required urgent assistance, floodwaters continued to rise, or a hostile army continued to advance. This gave Bush some time, and therefore allowed the principal advisors and their back offices to proceed relatively methodically in gathering further information and designing policy options.

The Katrina crisis. At a strategic level, Katrina presented Bush with a situation in which he would be forced to decide the degree and form of federal support to be provided and, when things were looking increasingly desperate, whether to initiate a full federalization of the disaster response, possibly with the president taking personal control of any federal intervention and support effort. The need to dramatically step up federal efforts became increasingly apparent during the last days of August, when Bush began to 
understand that the key players at the local, state, and federal levels did not have at their disposal enough emergency management competence and resources to meet operational needs. Bush initially did not get that impression from his regular advisors, and had concluded that although widespread and devastating, Katrina was essentially just another "routine hurricane" as far as the federal role was concerned; the existing cluster of federal executives and agencies, he argued, were coping well (hence the now notorious suggestion that "Brownie, you're doing a heck of a job;" Brown in fact was at the time in the process of being removed and replaced by DHS secretary Chertoff, thus becoming the first scapegoat in the unfolding politics of blame in the wake of Katrina). It took personal observation to galvanize Bush in switching from a reactive to more proactive mode: first, seeing the flood damage from the air during a flyover by Air Force One; second, a compilation of news footage played for him during that same flight; third, and perhaps most poignant, the erratic and undiplomatic behavior of stressed Mayor Nagin on board Air Force One during Bush's subsequent field visit.

Yet when the need for federal intervention was finally realized, White House coordination and assistance efforts were greatly hampered by the fact that Bush could not make decisions single-handedly, as in a foreign or security crisis. For the intervention of federal forces, for instance, he had to acquire the support, or at least the acquiescence, of state governors. In Louisiana, where the situation was spinning out of control, this presented a problem. Relations between the White House and state officials had soured, as Governor Blanco's staff became convinced that the White House was engaging in a blame game. Alleged political machinations seriously compromised intergovernmental relations, greatly hampering the speed and quality of policy deliberation. The governor, holding out against what she saw as an attempt to discredit her administration, effectively vetoed the White House's initial proposal to send federal troops.

\section{Constructing Presidential Meaning Making: Communicative Capacity}

The 9/11 crisis. Following the attacks, the key presidential meaning-making challenges were to portray a caring yet in-control president, and to frame the crisis so as to bolster the credibility of the administration, galvanize Congress and the nation, and mobilize international support for the U.S. response. Bush rose to the occasion. Although his first two public statements on the day of the attacks were less than impressive, Bush recouped and pulled off the best performance of his career, and one that will likely be considered one of the most effective examples of presidential crisis communications ever. His key crisis speeches, first during the service at Washington Cathedral and then before Congress, succeeded in steeling the nation's resolve and heralded-for better or for worse-nothing less than a paradigm shift in U.S. foreign and security policy.

Bush's White House demonstrated a high level of communicative capacity during the 9/11 crisis. Not only were some of Bush's most trusted advisors-Hughes and Rove-crucial figures in the meaning-making segment of the advisory configuration; the entire communications arm of the Bush White house was well staffed, tightly run, and 
powerful during the early years of his presidency. Hughes and Rove were able to quickly convey to the president how significant the handling of this crisis would be to his presidency. Hughes, Rove, and speechwriters Michael Gerson, Matthew Scully, and John McConnell were invaluable to Bush in the meaning-making process, in effect co-developing the policy while framing the language in which it was to be promoted. Bush himself was receptive to the work of his advisors during the crisis: supportive yet demanding, and highly involved in drafting and fine-tuning key speeches. The message conveyed by the president and his administration was consistent throughout. On the first day, Bush conveyed the message that America had been attacked, but was not the victim, and would not allow the attacks to go unanswered. Subsequent speeches and public appearances amplified and elaborated this theme, to great popular and political acclaim.

The Katrina crisis. During Katrina, the meaning-making task was equally daunting, albeit in a completely different way. Bush again had to be presented as informed, compassionate, and in control — this time in the context of a domestic emergency, where the initial response effort fell squarely on other levels of government, and where there was no enemy perpetrator to rally against. Bush furthermore had to credibly reassure the public that-media coverage of increasingly desperate evacuees, growing lawlessness, and a totally disorganized response effort notwithstanding-sufficient (federal) resources and forces were being mobilized to provide order and assistance. As the crisis escalated, he had to deal with a growing chorus of bitter, threefold criticism regarding the perceived lack of preparedness; the chaotic, ineffective government response; and his own apparent lack of concern and passivity in the face of unprecedented community distress and allegations of racism as having contributed to the miserable situation in the poorest and hardest-hit areas. (This last sentiment was epitomized by rapper Kanye West's unscripted remarks during a televised benefit concert on September 2, here suggesting that "George Bush doesn't care about black people.")

Comparing the well-received Washington Cathedral speech and congressional addresses after 9/11 to Katrina, President Bush gave what could be considered a counterpoint speech in New Orleans on September 15, 2005. This speech is not included in our analysis, as it falls outside the acute phase of the crisis and is notable for many reasons, not the least of which being that it further demonstrated the meaning-making lag, and is indicative of the inadequate communicative capacity of the Bush advisory configuration during the Katrina crisis. The Bush administration was still unsuccessfully attempting to "teach reality" nearly two weeks after the immediate emergency response on the ground was essentially under control, if not concluded.

The Katrina crisis can be considered the defining event of President Bush's second term, and four years after $9 / 11$, his reputation as an effective crisis manager had disintegrated. The administration lost control of the crisis narrative from the first critical hours, and never managed to regain it. Bush and his administration looked out of touch and disengaged from the disaster. This was highlighted by several widely publicized symbolic gaffes: the flyover photo-op, the "Trent Lott's house" episode, overorchestrated site visits, the president's assertions that the levees had broken later than they actually had, and the aforementioned "Brownie" comment. Disagreement regarding the flyover 
demonstrated both managerial and communicative failures in the advisory configuration and displayed less cohesion among top-tier advisors than was apparent in the acute phase of 9/11. According to former White House press secretary Scott McClellan, Karl Rove initially suggested that the president be seen "surveying the damage in New Orleans ... as he returns to D.C."; however, McClellan claims that at the time, he (supported by Dan Bartlett) argued that Bush would appear "out of touch and detached" and the matter was "put to rest" (McClellan 2008, 273-74). Yet soon after, Bartlett indicated to McClellan that "Karl was convinced we needed to do it - and the President agreed" (2008, 280). From August 29 onward, Bush's message of reassurance about an all-out and effective federal assistance effort seemed ever more painfully incorrect. Increasingly, Bush had to defend himself and his administration against accusations of incompetence and callousness.

All this happened not because the White House communications operation had somehow gravely deteriorated following Karen Hughes's departure. There were plenty of talented and experienced meaning-making experts on the communications team and part of the inner circle. The key problem was that much of the communications advice that Bush was getting was based on the same faulty and delayed sense making that handicapped the entire federal response, and advisors such as Rove were suggesting and implementing the same meaning-making script that had been so effective in the acute phase of $9 / 11$. The nature and depth of the meaning-making challenges of Katrina were therefore ill understood for too long by Bush's principal communications advisors, as well as Bush himself. Regarding the extent of the Katrina "problem" that McClellan recalled, "It would be a day or two before we would fully grasp it, but we had already blown our initial response to Katrina. In the process, we'd made ourselves vulnerable" (2008, 279). When the principals realized the gravity of the situation, the meaningmaking problem had already reached the level of a crisis within a crisis. Moreover, the shadow of the Iraq war loomed over Katrina, with growing criticism over incompetent and negligent war leadership, and realizations that National Guard troops posted in Iraq might have been put to better use during Katrina. Powerful evidence, images, and examples of inadequate leadership flowing from two crisis theaters simultaneously were very hard to overcome.

\section{Conclusions}

This article has sought to make a modest theoretical contribution. In our experience, the key distinctive components of the conceptual framework presented in Figure 1 - crisis-induced strategic leadership challenges, advisory configuration properties, and advisory configuration crisis performance-proved a useful prism through which to look at, sort, and interpret the mountains of data available about both cases. The notion of "advisory configuration" developed here will need to be further refinedparticularly when it comes to demarcating more clearly which actors and activities should be considered part of "advisory back offices" and which should not-but at least it does allow for a flexible, inclusive, contingent, and empirically grounded understanding 
of where leaders obtain their information, ideas, texts, and other forms of support in concrete historical episodes, which existing conceptualizations have not quite managed to capture. Similarly, the trichotomy of crisis advisory capacity, as derived from existing work on crisis leadership, allows for a more nuanced assessment of advisory performance, whereas many prior studies have focused on the analysis and decision-making functions, missing the vital role of leadership support in the sense-making domain.

Turning to the substance of the chief puzzle and claim stated at the outset of this article, the evidence is strongly suggestive, but is not-and cannot be, in this type of research design — conclusive. Clearly, there were pivotal differences in the makeup and modus operandi of the advisory configurations that Bush relied on to cope with 9/11 and Katrina. And equally clearly, the 9/11 advisory configuration rose to the challenge of the events, whereas the Katrina configuration was demonstrably instrumental in giving Bush a deeply flawed, overoptimistic picture of the damage done by Katrina and the extent to which its impact far outstripped local and state response capacities. As a result, Bush was one if not several steps behind events and emotions "on the ground" right from the start, and never really caught up. This affected the performance of the two other crisis leadership tasks. Few strategic White House decisions were required during the first week of Katrina, but the pivotal one - the release of massive federal military personnel and other resources-became a case of "too little, too late." Moreover, and largely for the same reason, the depth of the meaning-making challenges facing Bush was severely underestimated. For several days, Bush was advised to continue in "business as usual" mode, which made him look out of touch, if not outright indifferent. A downward credibility spiral was set in motion: when he did employ some of the same meaningmaking techniques that had been so successful in enhancing his communicative performance during 9/11 (photo-ops during flyovers, site visits, speeches), they backfired completely given the graphic discrepancy between his gestures of reassurance and the frightening reality of abandoned victims on display for all to see.

In our conceptual framework, we put forward the proposition that three features of the advisory configuration shape advisory crisis capacity: the level and distribution of expertise, the degree of mental and organizational preparedness for the type of crisis, and the degree of vertical and horizontal coordination. Juxtaposing analyses of their influence in the two cases has indicated their impact on presidential crisis leadership. The acute phase of 9/11 saw these three features take on relatively benign values, producing an advisory configuration that proactively and effectively facilitated Bush's leadership performance. In contrast, during the Katrina crisis, the absence or decreased presence of these three components of a robust crisis advisory configuration hindered, and probably actively worked against, effective presidential crisis leadership.

Where the 9/11 Commission attributed the occurrence of the attacks to a "failure of imagination," the Select Bipartisan Committee of the House of Representatives (2006) framed the bungled response to Katrina in terms of a "failure of initiative" and lack of clear leadership. The analysis here suggests that the contrast should not be overdrawn: Bush's leadership during Katrina suffered because neither he, nor his inner circle, nor the vital gatekeepers of information about the hurricane impact flowing to the White House had the imagination to grasp that the worst-case scenario (cf. Clarke 2006) that had been 
talked about for such a long time (and that Bush et al. had been briefed on just days before Katrina's landfall) had actually materialized. With the sense-making foundation on which crisis leadership inevitably rests being so misguided and disorganized, Bush and his inner circle were bound to fall short in those first few days of the Katrina catastrophe (see also U.S. Senate 2006). In contrast to the 9/11 case, during which the president needed no persuasion to be come engaged instantly and enduringly, throughout Katrina, Bush was lulled into maintaining an essentially reactive posture, thus depriving the advisory configuration around him of a key animating force that had prompted it to perform so well four years before.

This is certainly not unique: during the tsunami crisis of 2004, some (but not all) Western governments failed to make the conceptual leap toward worst-case thinking and acting quickly enough. As a result, key government leaders were caught out, and appeared as incompetent as Bush, losing precious leadership capital in the process (cf. Brändström, Kuipers, and Daléus 2008). Given that these events occurred in the post9/11 world, where presumably issues of crisis management capacity have risen to unprecedented prominence on governmental agendas around the world, one cannot help but wonder whether some of the reforms that were made in response to 9/11 did not in fact unwittingly diminish rather than enhance that very capacity. Katrina showed for the United States, as the tsunami did for some other Western countries, that perhaps the so-called lessons of 9/11 had been learned too well, creating systems of intelligence, preparedness, and response that paid lip service to an "all hazards" approach but instead reflected an understandable but fundamentally flawed preoccupation with only one hazard category, namely terrorism. Major crises create powerful historical analogies, and this may be, more often than not, a handicap to learning from experience (Brändström, 't Hart, and Bynander 2004). It remains to be seen what sort of funnel for long-term policy learning and future crisis sense-making the Katrina experience will provide.

\section{References}

9/11 Commission. 2004. The 9/11 Commission Report: Final report of the National Commission on Terrorist Attacks upon the United States. New York: W. W. Norton.

Bakvis, H. 1995. "Advising the Executive: Think Tanks, Consultants, Political Staff and Kitchen Cabinets." In The bollow Crown: Countervailing Trends in Core Executives, eds. P. Weller, H. Bakvis, and R. A. W. Rhodes. New York: St Martin's Press, 84-125.

Bier, V. 2006. "Hurricane Katrina as a Bureaucratic Nightmare." In On Risk and Disaster: Lessons from Hurricane Katrina, eds. R. J. Daniels, D. F. Kettl, and H. Kunreuther. Philadelphia: University of Pennsylvania Press, 243-54

Bligh, M. C., J. C. Kohles, and J. R. Meindl. 2004. "Charisma under Crisis: Presidential Leadership, Rhetoric, and Media Responses before and after the September 11th Terrorist Attacks." Leadership Quarterly 15 (April): 211-39.

Blight, J. G. 1990. The Shattered Crystal Ball: Fear and Learning in the Cuban Missile Crisis. Savage, MD: Rowman \& Littlefield.

Boin A., P. 't Hart, E. K. Stern, and B. Sundelius. 2005. The Politics of Crisis Management: Public Leadership under Pressure. New York: Cambridge University Press.

Brändström, A., P. ‘t Hart, and F. Bynander. 2004. "Governing by Looking Back: Historical Analogies and Crisis Management." Public Administration 82: 191-210. 
Brändström, A., S. Kuipers, and P. Daléus. 2008. "The Politics of Blame Management in Scandinavia after the Tsunami Disaster." In Governing after Crisis: The Politics of Investigation, Accountability and Learning, eds. A. Boin, P. 't Hart, and A. McConnell. New York: Cambridge University Press.

Burke, J. P. 2004. Becoming President: The Bush Transition, 2000-2003. Boulder, CO: Lynne Rienner. . 2005. "Condoleezza Rice as NSC Advisor: A Case Study of the Honest Broker Role." Presidential Studies Quarterly 35 (September): 554-75.

Burke, J. P., and F. Greenstein. 1989. How Presidents Test Reality. New York: Russell Sage Foundation.

Campbell, C., and M. Wyszomirski, eds. 1991. Executive Leadership in Anglo-American Systems. Pittsburgh: Pittsburgh University Press.

Clarke, L. 2006. Worst Cases: Terror and Catastrophe in the Popular Imagination. Chicago: University of Chicago Press.

Cooper, C., and R. Block. 2006. Disaster: Hurricane Katrina and the Failure of Homeland Security. New York: Times Books.

Garrison, J. 2007. "Constructing the 'National Interest' in US-China Policy Making: How Foreign Policy Decision Groups Define and Signal Policy Choices." Foreign Policy Analysis 3: 105-26.

Garrison, J., P. D. Hoyt, and D. M. Wituski. 1997. "Managing Intragroup Relations in Foreign Policy." Cooperation and Conflict 32: 261-86.

George, A. L. 1980. Presidential Decisionmaking in Foreign Policy: The Effective Use of Information and Advice. Boulder, CO: Westview Press.

George, A. L., and E. K. Stern. 2002. "Harnessing Conflict in Foreign Policy Making: From Devil's to Multiple Advocacy." Presidential Studies Quarterly 32 (December): 484-508.

Goldhamer, H. 1978. The Adviser. New York: Elsevier.

Gregg, G. L., II. 2004. "Dignified Authority: George W. Bush and the Symbolic Presidency." In Considering the Bush Presidency, eds. G. L. Gregg II and M. J. Rozell. New York: Oxford University Press, 88-106.

Haney, P. J. 1997. Organizing for Foreign Policy Crises. Ann Arbor: Michigan University Press.

- 2005. "Foreign-Policy Advising: Models and Mysteries from the Bush Administration." Presidential Studies Quarterly 35 (June): 289-302.

Hargrove, E. 1998. The President as Leader. Lawrence: University Press of Kansas.

't Hart, P., E. K. Stern, and B. Sundelius, eds. 1997. Beyond Grouptbink: Political Group Dynamics in Foreign Policy. Ann Arbor: University of Michigan Press.

Hess, S., and J. P. Pfiffner. 2002. Organizing the Presidency. Washington, DC: Brookings Institution Press.

Holsti, O. R. 1972. Crisis, Escalation, War. Montreal: McGill-Queens University Press.

Hoyt, P. D., and J. Garrison. 1997. "Political Manipulation in the Small Group: Foreign Policy Advisers in the Carter Administration." In Beyond Groupthink: Political Group Dynamics in Foreign Policy, eds. P. 't Hart, E. K. Stern, and B. Sundelius. Ann Arbor: University of Michigan Press.

Hult, K. M., and C. E. Walcott. 2004. Empowering the White House: Governance under Nixon, Ford and Carter. Lawrence: University Press of Kansas.

Janis, I. L. 1982. Groupthink. Boston: Houghton Mifflin.

Johnson, R. T. 1974. Managing the White House. New York: Harper \& Row.

Kavanagh, D., and A. Seldon. 1999. The Powers Behind the Prime Minister: The Hidden Influence of Number Ten. London: Harper and Collins.

Kettl, D. F. 2003. Team Bush: Leadership Lessons from the White House. New York: McGraw-Hill.

Kowert, P. 2002. Groupthink or Deadlock: When Do Leaders Learn from Their Advisors? Albany: State University of New York Press.

Kumar, M. J. 2003. "Communications Operations in the White House of President George W. Bush: Making News on His Terms." Presidential Studies Quarterly 33 (June): 366-93.

Landy, M. 2004. "The Bully Pulpit and the War on Terror." In New Challenges for the American Presidency, eds. G. C. Edwards III and P. J. Davies. New York: Pearson Longman, 49-64.

Lewis, D. E. 2008. The Politics of Presidential Appointments: Political Control and Bureaucratic Performance. Princeton, NJ: Princeton University Press.

Liu, B. F. 2006. "President Bush’s Major Post-Katrina Speeches: Enhancing Image Repair Discourse Theory Applied to the Public Sector." Public Relations Review 33: 40-48. 
Mann, J. 2004. The Rise of the Vulcans: The History of Bush's War Cabinet. New York: Penguin.

McClellan, S. 2008. What Happened: Inside the Bush White House and Washington's Culture of Deception. New York: Public Affairs.

McQuaid, J., and M. Schleifstein. 2006. Path of Destruction: The Devastation of New Orleans and the Coming Age of Superstorms. New York: Little, Brown.

Meltsner, A. 1988. Rules for Rulers: The Politics of Advice. Philadelphia: Temple University Press.

Milburn, T. W. 1972. "The Management of Crisis." In International Crises: Insights from Behavioral Research, ed. C. F. Hermann. New York: Free Press, 259-77.

Mitchell, D. 2005. "Centralizing Advisory Systems: Presidential Influence and the U.S. Foreign Policy Process." Foreign Policy Analysis 2: 181-206.

Patterson, B. 2000. The White House Staff: Inside the West Wing and Beyond. Washington, DC: Brookings Institution Press.

Pfiffner, J. P. 2005. "Presidential Decision Making: Rationality, Advisory Systems, and Personality." Presidential Studies Quarterly 35 (June): 217-28.

Poguntke, T., and P. Webb, eds. 2005. The Presidentialization of Politics: A Comparative Study of Modern Democracies. New York: Oxford University Press.

Preston, T. 2001. The President and His Inner Circle. Princeton, NJ: Princeton University Press.

2008. "Weathering the Politics of Responsibility and Blame: The Bush Administration and Its Response to Hurricane Katrina." In Governing after Crisis: The Politics of Investigation, Accountability and Learning, eds. A. Boin, P. 't Hart, and A. McConnell. New York: Cambridge University Press, 33-61.

Preston, T., and M. G. Hermann. 2004. "Presidential Leadership Style and the Foreign Policy Advisory Process." In The Domestic Sources of American Foreign Policy: Insights and Evidence, 4th ed., eds. E. R. Witkopf and J. M. McCormick. Lanham, MD: Rowman \& Littlefield, 363-80.

Redd, S. B. 2005. "The Influence of Advisers and Decision Strategies on Foreign Policy Choices: President Clinton's Decision to Use Force in Kosovo." International Studies Perspectives 6: 12950.

Roper, J. 2004. "The Contemporary Presidency: George W. Bush and the Myth of Heroic Presidential Leadership." Presidential Studies Quarterly 34 (March): 132-42.

Rosenthal, U., M. T. Charles, and P. 't Hart, eds. 1989. Coping with Crisis: The Management of Disasters, Riots, and Terrorism. Springfield, IL: Charles C. Thomas.

Rosenthal, U., and P. 't Hart. 1991. "Experts and Decision Makers in Crisis Situations." Knowledge: Creation, Diffusion, Utilization 12: 350-72.

Rudalevige, A. 2005. "The Structure of Leadership: Presidents, Hierarchies, and Information Flow." Presidential Studies Quarterly 35 (June): 333-60.

Select Bipartisan Committee to Investigate the Preparation for and Response to Hurricane Katrina. 2006. A Failure of Initiative: Final Report of the Select Bipartisan Committee to Investigate the Preparation for and Response to Hurricane Katrina. Washington, DC: Government Printing Office.

Sullivan, T., ed. 2004. The Nerve Center: Lessons in Governing from the White House Chiefs of Staff. College Station: Texas A\&M University Press.

Sylves, R. 2006. "President Bush and Hurricane Katrina: A Presidential Leadership Study." Annals of the American Academy of Political and Social Sciences 604: 26-56.

Tiernan, A. 2007. Power Without Responsibility. Sydney: UNSW Press.

U.S. Congress. Senate. Committee on Homeland Security and Governmental Affairs. 2006. Hurricane Katrina: A Nation Still Unprepared. Washington, DC: Government Printing Office.

Vaughn, J. S., and J. D. Villalobos. 2006. "Conceptualizing and Measuring White House Staff Influence on Presidential Rhetoric." Presidential Studies Quarterly 36 (December): 681-88.

Walcott, C. E., and K. M. Hult. 1995. Governing the White House: From Hoover through LBJ. Lawrence: University Press of Kansas.

— 2005. "White House Structure and Decision Making: Elaborating the Standard Model." Presidential Studies Quarterly 35 (June): 303-18.

Walcott, C. E., S. A. Warshaw, and S. J. Wayne. 2001. "The Chief of Staff." Presidential Studies Quarterly 31 (September): 464-89. 
White House. 2006. The Federal Response to Hurricane Katrina: Lessons Learned. Washington, DC: Government Printing Office.

Woodward, B. 2002. Bush at War. New York: Simon \& Schuster.

2008. The War Within: A Secret White House History, 2006-2008. Pymble, NSW: Simon \& Schuster Australia.

Yetiv, S. 2003. "Groupthink and the Gulf Crisis." British Journal of Political Science 33: 419-42. 